28. Collins English Dictionary. New York, 2006. URL: https://www.abbyy.com/en-ee/translation_dictionary (Last accessed: 10.06.2020).

29. Macmillan

Dictionary.

London,

2010.

URL: http://www.macmillandictionary.com. (Last accessed: 11.06.2020).

30. Oxford Dictionary of English. Oxford, 2010. URL: https://www.abbyy.com/en-ee/translation_dictionary (Last accessed: 11.06.2020).

УДК 811.111-112:81’371

DOI: $10.24144 / 2617-3921.2020 .18 .216-225$

Сніжана Голик

кандидат філологічних наук, дочент, завідувачка кафедри англійської філології ДВНЗ “УжНУ”

ORCID 0000000312783383

Ужсгород, Україна, +380503727340,

snizhana.holyk@uzhnu.edu.ua

\title{
Етимологічний шар концепту OLD AGE
}

Анотаиія. Останні десятиліття характеризуються посиленням уваги науковиів до проблем старіння та людей похилого віку. Метою аналізу у запропонованій статті є комплексне дослідження концептуалізаџї̈ старості в англомовній картині світу. $У$ статті представлено результати встановлення передконщептуальних засад OLD AGE шляхом визначення етимону та внутрішньої форми лексеми old age - імені концепту та ї̈ синонімів. Актуальність дослідження визначається зверненням до історичного розвитку вербалізованих концептів, щуо сприяе аналізу мови 3 точки зору ї̈ участі у когнітивній діяльності людини. Визначення етимологіі ключової лексеми дозволяє зрозуміти послідовність становлення семантичних ознак кониепту. Об'єктом розвідки є концепт OLD AGE, вербалізований лексичними одинииями англійської мови. Предмет дослідження-особливості етимологічного розвитку номінативної лексеми old age, ï̈ синонімів та прикметника old, a також встановлення асоціацій, релевантних поняттю “старість". Матеріалом слугували як теоретичні розробки сучасних лінгвістів, присвячені дослідженню етимології концептів та їхньому історичному розвитку, так і етимологічні словники англійської мови. Зроблено висновок про те, що встановлення етимології імені концепту передбачає проведення етимологічного лексикографічного аналізу засобів його мовного вираження. Поняття внутрішньої форми відображає образи та 
ідеї, які лежать в основі номінації, а внутрішня форма слова нерозривно пов'язана з його етимоном. Це дає змогу вивчити первинний смисл досліджуваних лексем $i$ встановити етимологічний шар конщепту. $У$ результаті дослідження зроблено висновок, щзо етимоном лексеми old age (n) $\epsilon$ значення “похилі роки”, в основі якого лежить негативна оцінка, яка, на нашу думку, $i$ визначає внутрішню форму лексеми old age. Визначений етимологічний шар виступає складовою частиною змістового мінімуму конщепту. Перспективи подальших досліджень вбачаємо в аналізі поняттєвої складової концепту OLD AGE у різних типах дискурсу.

Ключові слова: конщепт, структура конщепту, етимологічний аналіз, внутрішня форма, етимон, old age.

Abstract. Recent years have been characterized by the rise of researchers' attention to the problems of the elderly and the issues of ageing. The author of the present paper explores the complex and changing conceptualisation of old age and its discourses. The article focuses on the pre-conceptual basis of the concept OLD $A G E$ in the English worldview. Firstly, the survey of the complex research methodology is presented that provides the basis for the research into the nature and structure of the concept as a multifaceted unit. This paper aims at describing the method of etymological analysis and its role in disclosing the primary content of the key lexeme and its synonyms, defining the etymological layer of the concept. The study of the historical development of verbalized concepts encourages not only the analysis of human language, but also the way it promotes cognition and helps understand the development of the concept's semantic features. It is emphasized that etymological lexicographical analysis of lingual means used to verbalize the concept can disclose the etymon and the inner form of the key lexeme. The notion of the inner form discloses images and ideas taken as the basis of the naming process, which is believed to be closely related to the notion of the etymon. The earliest form (etymon) and historical changes in the semantic structure of the corresponding lexemes constitute preconceptual features of the OLD AGE concept. Furthermore, the direction in the concept development is considered to be determined by the inner form of the concept's name which can help trace its etymology. According to etymological dictionaries, the lexeme old age dates back to the $14^{\text {th }}$ century with the meaning "period of life of advanced years". Research results show that the etymon of this lexeme is represented by the meaning "advanced years", based on the temporal feature when old age is regarded as final of the life stages, thus contributing to its negative stereotypical evaluation. This might define the inner form of the lexeme old age. The findings of the analysis provide implications for further studies of the concept OLD AGE in different types of discourse.

Keywords: concept, the structure of the concept, etymological analysis, inner form, etymon, old age.

Вступ. Сучасна лінгвістика демонструє зростання інтересу до мовного вираження важливих соціокультурних понять, серед яких чимале зацікавлення 
викликає поняття «старість». Люди здавна замислювалися над проблемами періодизації життєвого шляху та визначенням вікових концептів, вирішуючи ці проблеми у філософській, психологічній, біологічній, медичній, юридичній площині тощо. Лінгвістика сьогодення досліджує мову з точки зору її участі у когнітивній діяльності людини, тож звернення до історичного розвитку лексично втілених концептів надає актуальності нашій статті, метою якої $є$ встановлення передконцептуальних засад OLD AGE шляхом визначення етимону та внутрішньої форми лексеми old age - імені концепту, що сприятиме подальшій інтерпретації тих понять, які лежать в основі уявлень про старість.

За словами І.С. Шевченко, “методологічно діахронічні студії лексично втілених концептів спираються на загальні положення про розвиток мови і мовлення", які розвиваються разом із суспільством, «елементом якого є мова» [18, с.122], що, на думку дослідниці, цілком відповідає лінгвістиці антропологічної орієнтації. Тому мову сьогодні розглядають як основу для розуміння особливостей людського світосприйняття, а вивчення мови, за словами В. фон Гумбольдта, є “всесвітньою історією думок та почуттів людства" [6, с.27].

У сучасній лінгвоконцептології наголошується, що лінгвокультурні концепти потребують урахування національного менталітету певної епохи. Історичні концептологічні студії базуються на властивості концептів зазнавати трансформацій [17]. 3'ясування розвитку та визначення історичних трансформацій концептів дозволяє відслідкувати так звану “зміну орієнтирів поведінки у суспільстві” [7, с. 187]. Це залежить передусім від розвитку суспільних етичних та утилітарних норм поведінки [18, с.124].

Об'єктом нашої розвідки обрано концепт OLD AGE, вербалізований лексичними одиницями англійської мови, а предметом дослідження $\epsilon$ особливості етимологічного розвитку номінативної лексеми old age, iï синонімів та прикметника old, а також встановлення асоціацій, релевантних поняттю “старість”. Матеріалом статті слугували як теоретичні розробки сучасних лінгвістів, присвячені дослідженню етимології концептів та їхньому історичному розвитку, так і етимологічні словники англійської мови.

Методологія та методи дослідження. Аналіз сучасних методик і підходів щодо проведення концептуального аналізу переконливо демонструє застосування цілого ряду дослідницьких процедур, серед яких, передусім, виділяємо етимологічний аналіз. Пропонуючи методику аналізу лінгвокультурних концептів, Ю. С. Степанов у структурі концепту виділяє поняттєву та культурну складові, які, зі свого боку, також характеризуються складною будовою [15, с. 41].

Так, культурна складова утворена трьома шарами: історичним, етимологічним та актуальним. В історичному шарі на матеріалі етнографічних та енциклопедичних джерел, даних філософії та інших гуманітарних наук можна прослідкувати розвиток досліджуваного явища в 
усіх його виявах. Саме в цьому шарі концепту відображено відомості, які дозволяють визначати концепт OLD AGE як такий, котрий належить до універсальних концептів, з одного боку, і який набуває специфічних рис у картині світу відповідної спільноти, з іншого боку.

Одним із “основних інструментів пізнавального процесу для людини є iї мова" $[1$, с. 25]. Тому встановлення етимології імені концепту передбачає проведення етимологічного лексикографічного аналізу засобів його мовного вираження. Це дає змогу вивчити первинний смисл досліджуваних лексем i встановити етимологічний шар концепту.

Актуальний шар представлено лексичними ознаками мовних реперезентантів концепту, а саме ключової лексеми та їі синонімів, оскільки одне і теж саме поняття у свідомості індивіда може виражатися за допомогою різних мовних засобів. Також, важливим етапом аналізу є встановлення словотвірних ознак через аналіз похідних імені концепту, який дозволяє більш детально проаналізувати номінативне поле концепту і виокремити усі ті структури, які різною мірою відтворюють його основні ознаки.

Поняттсву складову можна встановити шляхом аналізу словникових дефініцій слів-репрезентантів концепту та визначенням семантичної структури.

Етимологічні відомості про лексему - ім'я концепту відображають прадавні значення, що лежать в основі внутрішньої форми цієї лексеми і формують доконцептуальні ознаки $[18$, с.122-123]. У термінології Ю. С. Степанова, ці відомості репрезентують історичний шар концепту [15, с. 42].

Етимологічний аналіз, на думку О.О. Селіванової, починається 3 установлення статусу слова у плані його успадкування мовою у процесі їі еволюції чи запозичення з іншої мови [14, с.154]. Окрім цього, Етимологічний аналіз концепту сприяє встановленню ознаки чи ознак, які формують мотиваційну базу найменування, що постає змістом процесу номінації [5, с.44]. Первинна інформація про ознаки концепту зафіксована як у свідомості носіїв мови, так і в знаках, які вживаються для вербалізації цього концепту. Саме тому для опису концепту OLD AGE необхідно з'ясувати його передконцептуальні властивості. У дослідженнях Ю. С. Степанова відзначаємо культурологічне тлумачення концепту, що зумовлює потребу в аналізі усього того, “що робить концепт фактом культури”, зокрема i дослідження етимології вербалізаторів концепту, передусім його імені. [15, с. 43, c.187]. I.M. Колегаєва при конструюванні номінативного поля вербалізованого концепту окремим етапом виділяє “етимологічні розвідки ядерних сем" [8, с.126].

Виклад основного матеріалу дослідження. Поняттєва сутність концепту OLD AGE в англомовній картині світу сягає тих когнітивних структур знань про старість, які склалися у ході розвитку суспільства в цілому. Відповідно, дослідження концепту OLD AGE в англійській лінгвокультурі має базуватися 
на ретельному вивченні етимології слів-номінантів концепту, чиї семантичні ознаки дозволяють глибше зрозуміти саму природу концепту.

Етимологічний аналіз проводиться за даними етимологічних словників й історичних тезаурусів, що розкривають походження слова, його найбільш ранні форми (етимон) й історичні зміни семантики відповідних лексем, таким чином, формуючи передконцептуальні ознаки концепту OLD AGE.

Напрям розвитку концепту зумовлений внутрішньою формою лексемиімені концепту, що сягає корінням ії етимології. Внутрішня форма має різні тлумачення в роботах різних лінгвістів. Абстрагуючись від термінологічних деталей, В. М. Манакін підсумовує, що внутрішня форма слова була “предметом обговорення спочатку для еллінів, пізніше - для В. фон Гумбольдта, Дж. Харріса, Г. Штейнталя, В. Вундта, А. Марті, інших учених і, особливо, - для О. О. Потебні” [9, с.35]. За словами мовознавця, “явище, яке сьогодні ми називаємо внутрішня форма слова й усвідомлюємо його як першооснову найменування, давні вчення намагалися пов'язати 3 пошуком першопричини буття та універсуму в різних поняттєво-концептуальних визначеннях" [там само, с.36].

Німецький термін “innere Sprachform”, уведений В. фон Гумбольдтом, означає “внутрішня форма мови”, іншими словами, “уміщене в структурі мови свідчення духу народу” [6, с.11]. Базовим постулатом, який висмуває цей дослідник, є те, що мова є світом, який знаходиться між зовнішніми явищами та людиною [6, с. 13]. Положення Гумбольдта виявляють глибинні культурноісторичні, а також лінгвокогнітивні чинники різноманітності мовних картин світу та особливостей внутрішньої форми слів різних мов як маніфестації такої різноманітності.

За визначенням О.О. Потебні, внутрішньою формою слова є відношення змісту думки до свідомості; вона показує, як людині уявляється ії власна думка [12, с. 98]. Саме у внутрішній формі міститься відбиток процесу найменування, т.б. утворення слова, тобто відкривають зв'язки найменувань 3 тими процесуальними діями, які закріпилися за словами. Внутрішня форма демонструє рух думки, який мав місце умомент виникнення слова [10, с. 113].

Хоча і для самого О. О. Потебні внутрішня форма $є$ багатозначним терміном, відомий учений розглядає ії не лише як фіксацію ознаки предмета в мові, але і як свого роду взаємодію між зовнішнім світом та мовою [11]. До того ж, наголошує О.О. Потебня, внутрішня форма є “найближчим етимологічним значення слова, способом, за допомогою якого виражається зміст" [13, с. 175]. Таким чином, поняття внутрішньої форми відображає образи та ідеї, які лежать в основі номінації, а внутрішня форма слова нерозривно пов'язана з його етимоном.

Етимон - це відновлювана початкова форма певної одиниці мови (кореня, слова, фразеологізму), зазвичай найбільш рання з відомих форм [2]. Етимологія виявляє принципи номінації та реконструює лексичний фонд, що становить інтерес не тільки для історичної лексикології, але й для вивчення 
історії відповідного суспільства, його матеріальної та духовної культури [4, с. 646].

Опираючись на ідею Ю. С. Степанова щодо наявності у концепту етимологічного шару, вважаємо, що в етимоні лексеми old age стереотипно закладено соціокультурне уявлення про старість в англомовній картині світу, яке $\epsilon$ результатом метафоричного переосмислення соціокультурних феноменів на підгрунті різноманітних асоціаціій.

Згідно 3 даними етимологічного словника [20], лексема old age уперше зафіксована на початку 14 ст. у значенні "period of life of advanced years" старші роки життя, літа. Це означає, що в основу номінації було покладено темпоральну ознаку, згідно з якою старість розглядали як один із життєвих періодів, а саме похилі роки.

Прикметник old (adj.) (від давньоанглійського ald (Anglian), eald (West Saxon, Kentish) вживався з цілим рядом значень, зокрема такими як:

- "antique, of ancient origin, belonging to antiquity, primeval";

- "long in existence or use";

- "near the end of the normal span of life";

- "elder, mature, experienced" [20].

Як бачимо, перші два значення вживалися на позначення віку матеріальних об'єктів (“античний, давнього походження, первісний”; “такий, що перебуває у довгому користуванні”), тоді як дві наступні вживаються щодо позначення віку людини (“близький до кінця життя”; “старший, зрілий, досвідчений").

Таблиця 1

Етимологія лексеми old

\begin{tabular}{|c|c|c|c|}
\hline Лексема & Мова & Значення & Переклад \\
\hline ald & Anglian & $\begin{array}{l}\text { near the end of the normal } \\
\text { lifespan; }\end{array}$ & $\begin{array}{l}\text { недалеко від } \\
\text { кінця життя }\end{array}$ \\
\hline eald & $\begin{array}{c}\text { West } \\
\text { Saxon/Kentish }\end{array}$ & elder, mature, experienced & $\begin{array}{c}\text { старший, } \\
\text { зрілий, } \\
\text { досвідчений }\end{array}$ \\
\hline *althas & $\begin{array}{c}\text { Proto- } \\
\text { Germanic }\end{array}$ & grown up, adult & дорослий \\
\hline ald & Old Frisian & grown up, adult & дорослий \\
\hline alpeis & Gothic & grown up, adult & дорослий \\
\hline oud & Dutch & grown up, adult & дорослий \\
\hline alt & German & grown up, adult & дорослий \\
\hline
\end{tabular}


Прикметник old походить від прагерманської форми (Proto-Germanic) *althaz, що означала "grown up, adult" (“дорослий”) і слугувала основою для утворення споріднених слів в інших германських мовах: наприклад, Old Frisian ald, Gothic alpeis, Dutch oud, German alt [20]. У мові-оригіналі ця форма відповідала основі дієприкметника минулого часу, що позначав "grow, nourish" ("рости, живити"), подібно до готського Gothic alan "to grow up", давньоскандинавського Old Norse ala "to nourish"), які походять від праіндоєвропейського кореня *al- "to grow, nourish" ("рости, живити, вирощувати") [20]. Внутрішня форма лексеми old фіксує вказану ознаку як динамічний процес зростання, дорослішання.

Аналізуючи значення давньоанглійських лексем ald (Anglian), eald (West Saxon/Kentish), відзначаємо наявність в їхній семантичній структурі дефініційних ознак, які вживаються на позначення завершення життєвого циклу людини [the end of the normal span of life] та старший, зрілий, досвідчений [elder, mature, experienced]. Зазначені семеми демонструють суперечливе ставлення до старості у наївній картині світу давніх англійців, які сприймали прихід цього періоду як негативно, у сенсі завершення життя, так $\mathrm{i}$ позитивно, як зрілість і досвідченість.

Також, варто відзначити вживання для вербалізації концепту OLD AGE ряду лексем 3 праіндоєвропейським коренем *sen- як, наприклад, у слові senior (старший, похилого віку). Згідно з етимологічним словником, у ряді індоєвропейських мов вживалися окремі слова на позначення особи старшого віку та старих речей, предметів і подій - old vs. young (person) на противагу old vs. new (thing) [20]. Латинське senex (“старий/літній”), яке походить від праіндоєвропейського слова *sénos (“старий”) вживалося на позначення людей похилого віку, тоді як vetus “старий, старовинний, давній, колишній” у Давньому Римі вживалося щодо предметів та речей. Лексема geriatric "related to old people,especially with regard to their healthcare" [19] походить від давньогрецького geraios, що вживалося по відношенню до осіб, тоді як palaios (від palai "long ago") позначало старовинні, давні предмети та поняття. Лексема archaic "very old or old-fashioned" походить від грецького слова arkhaios, що буквально перекладається як “той, що належить початку" ("belonging to the beginning"), яке паралельно з ancient (від французького ancient) вживається по відношенню до стародавніх, древніх речей "of former times, belonging to the distant past".

В давьоанглійський період також існувала лесема fyrn "ancient", у якій простежуються історичні зв'язки 3 feor “far, distant" (Old English віддалений), готським fairneis (Gothic), давньонорвезьким forn "old, of old, of former times"(Old Norse - колишній, давній) та давньоверхньонімецьким firni "old, experienced" (Old High German - старий, досвідчений) [20]. Як видно 3 наведених прикладів, лише в давньоверхньонімецькій мові в основу номінації покладено позитивну ознаку досягнення старшого віку людиною, 
решта ж лексичних одиниць в давньогерманських мовах не вживалися в контекстах, пов'язаних з віком людини.

Перша згадка про іменник age (n) в англійській мові датується 13 ст., коли його було запозичено з давньофранцузької (O. Fr. eded, edage, eage, aage, age - 12 ст.) - "age; life, lifetime, lifespan; maturity" [20] із значенням "long but indefinite period in human history “ (див. Таблиця 2).

Подальші етимологічні зв'язки дозволяють встановити його співвідношення з латинським aetatem (називний відмінок aetas) - "period of life, age, lifetime, years", від аеvит "lifetime, eternity, age", що походить від праіндоєвропейського кореня *aiw- "vital force, life; long life, eternity" (“енергійність, життя, довголіття, вічність”).

Таблиця 2

Етимологія лексеми age

\begin{tabular}{|c|c|c|c|}
\hline Лексема & Мова & Значення & Переклад \\
\hline aage, eage & Old French & $\begin{array}{l}\text { age; life, lifetime, lifespan; } \\
\text { maturity }\end{array}$ & $\begin{array}{c}\text { вік; життя; } \\
\text { життєвий } \\
\text { цикл; } \\
\text { зрілість } \\
\end{array}$ \\
\hline aetatem & Latin & $\begin{array}{c}\text { period of life, age, lifetime, } \\
\text { years }\end{array}$ & $\begin{array}{c}\text { період } \\
\text { життя, вік, } \\
\text { роки життя }\end{array}$ \\
\hline *aiw & $\begin{array}{c}\text { Proto- } \\
\text { IndoEuropean }\end{array}$ & $\begin{array}{c}\text { vital force, life; long life, } \\
\text { eternity }\end{array}$ & $\begin{array}{c}\text { життєва } \\
\text { енергія, } \\
\text { життя, } \\
\text { довголіття, } \\
\text { вічність } \\
\end{array}$ \\
\hline
\end{tabular}

В англійській мові іменник age у кінці 13 ст. витісняє давньоанглійську форму eld (Old English eald) на позначення "old age; an age; age as a period of life"- старість, вік, період життя. 314 ст. ця лексема часто вживається стосовно саме похилого (а не будь-якого) віку - "old age", а з середини 15 ст. набуває значення "effects of old age" (feebleness, senility, etc.) - "наслідки старості" (слабкість, старечість тощо) [20].

Таблиця 3

Історичний розвиток лексичних значень лексеми age

\begin{tabular}{|c|c|c|}
\hline Століття & Значення & Переклад \\
\hline 13 ст. & $\begin{array}{c}\text { long but indefinite period in } \\
\text { human history }\end{array}$ & $\begin{array}{c}\text { довгий невизначений } \\
\text { період в історії людства }\end{array}$ \\
\hline
\end{tabular}




\begin{tabular}{|c|c|c|}
\hline кінець 13 ст. & $\begin{array}{c}\text { old age; an age; age as a period of } \\
\text { life }\end{array}$ & $\begin{array}{c}\text { старість; вік; період } \\
\text { життя }\end{array}$ \\
\hline 14 ст. & old age & старість \\
\hline середина 15 ст. & $\begin{array}{c}\text { effects of old age (feebleness, } \\
\text { senility, etc.). }\end{array}$ & $\begin{array}{c}\text { наслідки старості } \\
\text { (слабкість, старечість) }\end{array}$ \\
\hline
\end{tabular}

Дієслівна форма age (v) із значенням "to grow old” (“старіти”) 3'являється у кінці 14 ст.

Висновки. Опираючись на інформацію, подану у словниках, та узагальнену у таблицях, можемо підсумувати, що етимоном лексеми old age (n) є значення “похилі роки", в основі якого лежить загальна ознака - "негативна оцінка", яка, на нашу думку, і визначає внутрішню форму лексеми old age (n.). Етимологічний аналіз інших лексем-вербалізаторів концепту OLD AGE прикметників old, senior, geriatric та іменника age демонструє розширення первинного значення. OLD AGE набуває негативного значення, символізуючи завершення життєвого етапу, наближення смерті. Водночас, старість пов'язана 3 дорослішанням людини, набуттям нею життєвого досвіду, зрілості. Отже, внутрішня форма концепту OLD AGE історично розвинулася від значень "кінець життя" та "слабкість, старечий вік" до позначення “зрілість, досвідченість", що і засвідчують етимологічні словники. Визначений етимологічний шар є складовою частиною змістовного мінімуму концепту. Перспективи подальших досліджень вбачаємо в аналізі поняттєвої складової концепту OLD AGE у різних типах дискурсу.

\section{ЛITEPAТУРА}

1. Болдырев Н.Н. Оценочные категории как формат знания . Исследование типов знаний и проблема их классификаиии. Сб. науч. тр. М.-Тамбов : Издательский дом ТГУ им. Г. Р. Державина (2008): 25- 37.

2. Большой Энщиклопедический словарь. 2000 [Електронний ресурс]. Режим доступу: \%DD\&word_id=72840. http://evoc.ru/index.php?voc_id=1\&letter=

3. Бондаренко Є.В. «Еволюція поняття часу в англійській мові та у дискурсі». Дис. док. філол. наук. Х. : ХНУ імені В.Н. Каразіна, 2012. 555 c.

4. Варбот Ж.Ж. Этимология: Русский язык. Энщиклопедия. М. : Большая Российская энциклопедия; Дрофа, 1997. С. 643-647.

5. Воркачев С. Г. Счастье как лингвокультурный концепт. М. : ИТДГК "Гнозис", 2004. 236c.

6. Гумбольдт В. фон. Избранные труды по языкознанию. М., 1984.

7. Карасик В. И. Языковые ключи. Волгоград : Парадигма, 2007. 520 с. 
8. Колегаєва I.M. Конструювання номінативного поля концепту: етапи та одиниці. Записки з романо-германської філологї̈. 2018 . № 1(40). С.121127.

9. Манакін В.М. Внутрішня форма слова в аспектах зіставного мовознавства. Мовознавство. 2014. № 5. С. 35-44.

10.Маслов Ю.С. Введение в языкознание. Уч. для вузов. М. : Высш. шк., 1987. 272c.

11.Потебня А. А. Мысль и язык [Електронний ресурс].Режим доступу : http://crecleco.seriot.ch/textes/POTEBNJA-MiJaz/10.html.)

12.Потебня А.А. Слово и миф. М., 1989.

13.Потебня А. А. Эстетика и поэтика. М. : Искусство, 1976. 613 с.

14.Селіванова О.О. Сучасна лінгвістика: термінологічна енщиклопедія. Полтава : Довкілля. К, 2006. 716 с.

15.Степанов Ю. С. Константы. Словарь русской культуры. Onыт исследования [Електронний ресурс]/Ю. С. Степанов. М. : Языки славянской культуры, 1997.825 с. Режим доступу: https://rucont.ru/efd/191844.

16.Стернин И. А. Методика исследования структуры концепта. Методологические проблеми когнитивной лингвистики: научное издание. Воронежкий госудаственный университет, 2001. С. 58-65.

17.Шевченко И.С. Концепты этики в диахронической перспективе. Человек. Язык. Культура. Сб. науч. ст., посвящ. 60-летнему юбилею проф. В.И. Карасика. Сер. «Кониептуальный и лингвальный миры» 2 К: Издат. дом Д. Бураго, 2013. Ч. 1. С. 472-480.

18.Шевченко I. С. Лексично втілені концепти: історичний вимір. Нова філологія. 2014. № 64. С.121-126 .

19. Collins English Dictionary and Thesaurus. Harper Collins Publishers, 1991. [Electronic resource]. Access : http://www.collinsdictionary.com.

20.Online Etymology Dictionary [Electronic resource]. Douglas Harper. Access: http://www.etymonline.com. 